\title{
Diversity of lionfishes (Pisces: Scorpaenidae) among remote coral reefs of the Palau Archipelago
}

Received: 17 April 2009/Accepted: 22 April 2009/Published online: 22 May 2009

(C) Springer-Verlag 2009
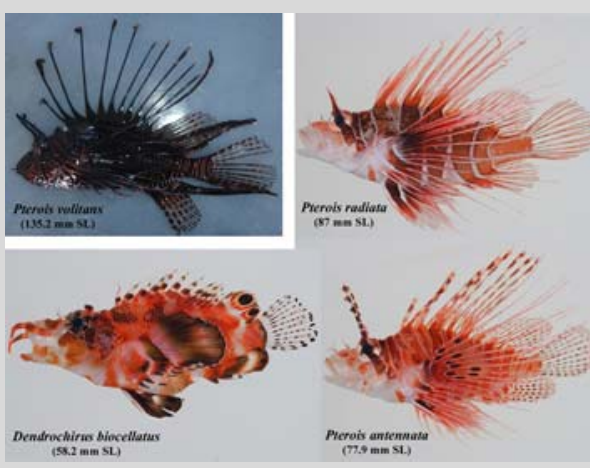

Fig. 1 Diversity of lionfishes collected among the southwest islands of Palau and the Helen Reef Atoll. $P$. volitans $(N=2)$ photo by J. Grubich. $P$. radiata $(N=6)$, $D$. biocellatus $(N=2)$, and $P$. antennata $(N=5)$ photos by J. Williams. Tissue loan requests and specimen collection information are available from the authors
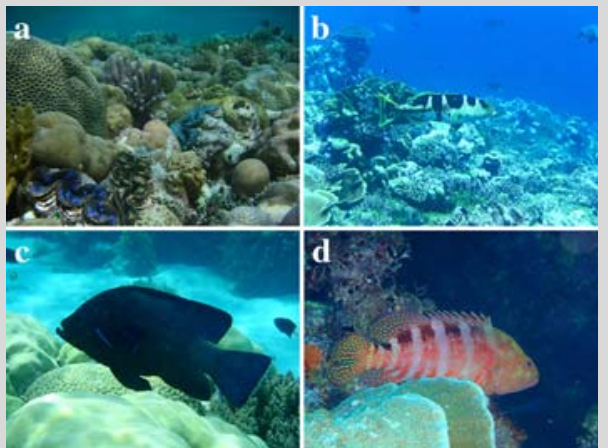

Fig. 2 Coral and grouper diversity (Serranidae). Helen Reef Atoll coral species and habitat complexity (a) photo by H. Rall. Plectropomus laevis (b) photo by M.Westneat. Aethaloperca rogaa (c) and Cephalopholis sexmaculata (d) photos by $\mathrm{M}$. Winterbottom
In less than a decade, the Indo-Pacific red lionfish, Pterois volitans, has rapidly spread throughout the Western North Atlantic (Whitfield et al. 2007). To improve understanding of the lionfish invasion, there is a pressing need for comparative knowledge on lionfishes from their native ranges.

During a 2008 rapid assessment of reef fish diversity among the Southwest Islands of the Palau Archipelago, lionfishes were collected while SCUBA diving using spears and by dispersing $4 \mathrm{~kg}$ of the ichthyotoxin rotenone at positions along the reef. Collection depths ranged from 2 to $36 \mathrm{~m}$, and seawater temperatures varied from $26-28.2^{\circ} \mathrm{C}$. A total of 15 lionfish specimens were collected from the fringing reefs of Sonsorol, Fana, and Tobi islands and the Helen Reef Atoll (Lat $2^{\circ} 52^{\prime} \mathrm{N}$, Long $131^{\circ} 46^{\prime}$ E). Four species of lionfishes were identified (Fig. 1).

Lionfishes were present in $28.9 \%$ of the sites accounting for only a small portion of the overall reef fish biodiversity. Unlike the high abundances of $P$. volitans in the Western Atlantic (i.e., 21.2-390 individuals ha $^{-1}$ ) (Whitfield et al. 2007; Green and Cote 2009), conservative estimates from Helen Reef Atoll ( $N=28$ sites; average rotenone collection area $\sim 13 \mathrm{~m}^{2}$ ) were relatively low for all four species (i.e. Pterois antennata $\sim 4.4$ ind $\mathrm{ha}^{-1}$, Pterois radiata $\sim 13.1$ ind $\mathrm{ha}^{-1}$, and $\sim 2.2$ ind ha ${ }^{-1}$ for Dendrochirus biocellatus and $P$. volitans).

In contrast to the Western Atlantic, lionfish were not observed roaming in the open. They were collected hiding in the reef matrix (Fig. 2a). The lower abundances and cryptic behavior may be related to high reef fish diversity limiting resources and increasing mortality. Groupers (Serranidae) have been indicated as potential predators as well as competitors of lionfishes (Maljkovic and Van Leeuwen 2008). This expedition encountered robust grouper populations identifying over 20 species from 7 genera (Fig. 2b-d).

Since lionfishes remain popular in the aquarium trade, there is still the threat of future introductions of new Pterois species into the Atlantic. These data provide a snapshot of lionfish biodiversity from a remote and still pristine coral reef ecosystem in the Western Pacific.

Acknowledgments We thank our collaborators Richard and Marina Winterbottom, Jeff Williams, Pat and Lori Colin, Brad Hubley and Wouter Holleman, and dive managers Paul Collins and Henni Rall. Special thanks go out to the Helen Reef Rangers and Southwest Islanders of Palau.

\section{References}

Green SJ, Cote IM (2009) Record densities of Indo-Pacific lionfish on Bahamian coral reefs. Coral Reefs 28:107

Maljkovic A, Van Leeuwen TE (2008) Predation on the invasive red lionfish, Pterois volitans (Pisces:Scorpaenidae), by native groupers in the Bahamas. Coral Reefs 27:501

Whitfield PE, Hare JA, David AW, Harter SL, Munoz RC, Addison CM (2007) Abundance estimates of the Indo-Pacific lionfish Pterois volitans/miles complex in the Western North Atlantic. Biol Invasions 9:53-64

\section{J. R. Grubich $(\bowtie)$}

U.S. Department of State, Washington, DC 20520, USA

e-mail: justinrg@gmail.com

M. W. Westneat · C. L. McCord

The Field Museum of Natural History, 1400 Lakeshore Dr, Chicago, IL 60605, USA

M. W. Westneat

e-mail: mwestneat@fmnh.org

C. L. McCord

e-mail: cmccord805@gmail.com

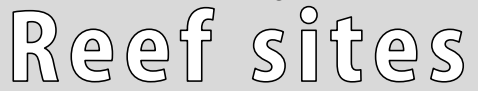

Coral Reefs (2009) 28:807 DOI $10.1007 / \mathrm{s} 00338-009-0510-\mathrm{z}$ 